\title{
Implementasi model pembelajaran project based learning untuk meningkatkan kreativitas gerakan jurus prasetya
}

\section{Implementation of project based learning model learning to improve the creativity of the jurus presetya movement}

\author{
Nancy Trisari Schiff ${ }^{1}$ \\ ${ }^{1}$ Program studi PJKR, STKIP Pasundan, Cimahi, Jawa Barat, 40512, Indonesia
}

\begin{abstract}
Abstrak
Tujuan penelitian ini untuk meningkatkan kreativitas mahasiswa dalam mempelajari jurus prasetya pencak silat dengan menerapkan model pembelajaran project based learning. Metode penelitian eksperimen. Populasi mahasiswa PJKR STKIP Pasundan dengan sample sebanyak 30 mahasiswa kelas $3 \mathrm{E}$ menggunakan teknik random sampling. Instrumen penelitian menggunkan angket kreativitas. Pengolahan data dilakukan dengan menggunakan metode Paired Sample T-test. Hasil penelitian dari pembelajaran pencak silat jurus prasetya dengan menerapkan model project based learning yang dilihat dari proses pembelajaran menunjukkan bahwa kreativitas mahasiswa meningkat dari observasi awal yang memiliki nilai rata-rata minimal sebesar 2,39 dan nilai rata-rata maksimal sebesar 3,58 dan saat dilakukan tes akhir menggunakan angket kreativitas yang sama hasilnya menjadi meningkat signifikan dengan nilai rata-rata minimal 3,30 dan hasil nilai rata-rata maksimal sebesar 4,36. Kesimpulan penelitian model pembelajaran project based learning meningkatkan kreativitas mahasiswa dalam proses pembelajaran pencak silat jurus prasetya.
\end{abstract}

Kata kunci: Model Pembelajaran Project Based Learning, Jurus Prasetya.

\begin{abstract}
The purpose of this study is to improve student creativity in learning jurus prasetya pencak silat by applying the project based learning model. Experimental research methods. Population student of PJKR STKIP Pasundan with sample of 30 from $3 E$ grade students using random sampling techniques. Research instruments use a creativity questionnaire. Data processing was performed using the paired sample T-test. The results research from learning of jurus prasetya pencak silat by applying the project based learning model which is seen from the learning process shows that students creativity increases from initial observations that have a minimum average value of 2.39 and a maximum average value of 3.58 and during the final test is done using the same creativity questionnaire the results become significantly increased with an average value of at least 3.30 and a maximum average value of 4.36. The conclusion of reasearch project based learning model can increases student creativity in the learning process of Jurus Prasetya pencak silat.
\end{abstract}

Keywords: Project Based Learning model, Jurus Prasetya.

\section{PENDAHULUAN}

Mengajar adalah suatu kegiatan yang bertujuan untuk melihat hasil apa yang dapat dicapai. Dalam dunia pendidikan khususnya bagi seorang pengajar harus bisa 
menyampaikan materi ajar dengan cara yang tepat agar peserta didik mampu menangkap apa maksud dari pembelajaran yang pengajar sampaikan. Biasanya seorang pengajar menggunakan berbagai macam cara (model pembelajaran) atau menggunakan berbagai macam alat sungguhan atau juga menggunakan alat modifikasi untuk dapat membuat pembelajaran yang di hasilkan menarik minat peserta didik dan dapat menyita perhatian peserta didik yang bertujuan untuk meningkatkan kemampuan mahasiswa selama proses pembelajaran. Pengajar dengan memilih model pembelajaran yang tepat juga bisa diharapkan mahasiswa bukan hanya sebatas belajar tetapi mahasiswa juga memiliki kemampuan berfikir kreativ, kritis dan memiliki pemahaman yang baik (Bereiter \& Scardamalia, 2000).

Model pembelajaran adalah suatu pola atau perencanaan yang digunakan sebagai pedoman dalam merencanakan pembelajaran di dalam kelas ataupun di luar kelas, model pembelajaran mengacu pada pendekatan pembelajaran yang akan digunakan, termasuk di dalamnya tahapan-tahapan dalam kegiatan pembelajaran, tujuan-tujuan pengajaran, lingkungan pembelajaran dan bagaimana cara pengelolaan kelas(Wahida et al., 2015). Selain itu Model pembelajaran dipergunakan untuk mencapai tujuan yang telah ditetapkan. Dalam kegiatan pembelajaran, metode diperlukan oleh pengajar agar penggunaanya bervariasi sesuai yang ingin dicapai setelah proses pembelajaran berakhir.

Pemilihan model pembelajaran yang tepat tentu akan memberikan solusi sebaik mungkin dan tercapainya tujuan dalam pelaksanaan pembelajaran. Model pembelajaran adalah suatu sarana untuk menguji, mencari dan menyusun data yang diperlukan bagi pengembangan suatu disiplin ilmu. Dalam hal ini metode bertujuan untuk memudahkan proses-proses pembelajaran sehingga apa yang sudah di rencanakan bisa tercapai dengan hasil yang maksimal dan dengan cara yang semudah mungkin. Dari pemaparan di atas tadi dapat disimpulkan bahwa pada intinya model pembelajaran adalah tahapan atau cara yang digunakan dalam interaksi antara pengajar dan mahasiswa untuk mencapai tujuan pembelajaran yang telah ditetapkan sesuaui dengan materi dan metode pembelajaran dan bertujuan mengantarkan suatu pembelajaran ke arah tertentu dengan cepat dan sesuai apa yang diinginkan.

Adapun manfaat dari model pembelajaran yaitu mendorong tumbuhnya rasa senang mahasiswa terhadap pelajaran, meningkatkan motivasi juga kreativitas dalam belajar, memudahkan mahasiswa mencapai hasil belajar yang lebih baik. Di dalam dunia pendidikan seorang pengajar perlu menguasai berbagai macam model pembelajaran karena keberhasilan pembelajaran seorang pengajar bisa dibilang berhasil ketika menggunakan model pembelajaran dan metode yang tepat sehingga tercapai tujuan dari 
setiap pembelajaran dan mampu mengendalikan mahasiswa sehingga tetap merasa senang dan tidak jenuh saat perkuliahan(Solomon, 2008). Berdasarkan pemaparan di atas dapat disimpulkan bahwa model pembelajaran adalah suatu cara yang dipakai oleh pengajar untuk menyampaikan materi-materi pembelajaran kepada mahasiswa baik di dalam kelas maupun di luar kelas agar materi pembelajaranpun tersampaikan dengan baik maksud dan tujuannya (Izzati, 2014).

Biasanya seorang pengajar yang sudah ahli dalam mengajar akan pintar memilih model pembelajaran untuk diterapkan saat pengajar itu akan mengajar. Bisa memadukan dua atau lebih model pembelajaran agar membuat pembelajaran semakin menyenangkan dan pastinya meminimalisir rasa kebosanan mahasiswa saat belajar. Dan sebaliknya bila seorang pengajar tidak pandai merencanakan dan menguasai kelas pasti pengajar itu akan keteteran saat mengajar dan mahasiswa juga akan merasa bosan. Model pembelajaran dapat dijadikan formasi mengajar, yang berarti pengajar bisa memilih model yang sesuai dan efisien untuk mencapai tujuan pembelajarannya.

Dalam pengimplementasian suatu model pembelajaran seorang pengajar harus memiliki ilmu pengetahuan dan pemahaman yang lebih agar dapat menjalankan suatu model pembelajaran dengan baik di dalam kelas. Pengajar juga harus memahami keadaan sarana dan prasarana yang ada di dalam kampus tersebut dan mengaitkan dengan rencana yang akan dipakai saat mengajar. Pengajar yang tidak dapat memahami kondisi ini biasanya cenderung tidak dapat meningkatkan keterampilan mahasiswa secara optimal dalam pembelajaran, pesan-pesan dan tujuan-tujuan dari pembelajaranpun kurang di fahami oleh mahasiswa khususnya dalam meningkatkan keterampilan pencak silat(Ayu et al., 2018).

Pembelajaran pada tingkat pendidikan tinggi perlu mendapatkan perhatian khusus. Strategi pembelajaran yang digunakan pengajar juga perlu dikembangkan. Tidak hanya sekedar memberi tugas yang banyak tapi minim evaluasi, namun juga pembelajaran yang harus memacu kemandirian, kreativitas belajar dan kemampuan berfikirnya. Kemampuan belajar mandiri tentu diperlukan peserta didik untuk menghadapi tugas mandiri, tugas kelompok maupun tugas akhir (Solomon, 2008).

Hasil observasi di lapangan yang telah peneliti lakukan, dalam pembelajaran mata kuliah pencak silat pengajar masih menggunakan metode komando dan ceramah sehingga mahasiswa merasa jenuh dan bosan saat perkuliahan berlangsung karena pembelajaran terasa monoton dan membosankan, dengan gerakan yang diulang-ulang tanpa ada varias dan menyebabkan sebagian mahasiswa lebih sering terlihat kurang focus dalam pembelajaran. Proses pembelajaran hanya berpusat pada pengajar, sehingga 
mahasiswa tidak diberikan kesempatan untuk berkreativitas mengembangkan dari gerak dasar jurus yang diberikan.

Berdasarkan hal tersebut, maka perlu dilakukan perlakukan atau treatment berupa penerapan model pembelajaran baru menggunakan model pembelajaran berbasis proyek (project based learning) karena model pembelajaran ini mampu meningkatkan kreativitas mahasiswa dalam merangkai gerakan jurus pencak silat dan mengurangi jenuh dengan cara belajar yang sebelumya(Wurdinger \& Rudolph, 2009).

\section{METODE}

Penelitian ini merupakan penelitian eksperimen dengan rancangan penelitian TheOne Group Pretest Posttest Design(Fraenkel, Jack R., Wallen, 2009)

\begin{tabular}{lll}
\hline O1 & $\mathrm{X}$ & $\mathbf{O 2}$ \\
\hline
\end{tabular}

Gambar 1. The One Group PretestPosttest Design (Fraenkel, Jack R., Wallen, 2009)

Keterangan:

$\mathrm{X}:$ Treatment/Perlakuan yang diberikan

O1: Tes awal (pretest) kelompok eksperimen

O2: Tes akhir (posttest) kelompok eksperimen

Populasi dalam penelitian ini adalah mahasiswa Kelas 3E Jurusan PJKR STKIP Pasundan dengan jumlah mahasiswa 30 orang. Melalui teknik random sampling terpilihlah kelas 3E sebagai sampel keseluruhan penelitian dengan jumlah 30 orang.

Data yang dikumpulkan dalam penelitian ini adalah hasil belajar teori dan praktek perkuliahan Pencak Silat dan tingkat kreativitas mahasiswa. Tes yang dikembangkan dalam penelitian ini dan sebagai alat pengumpul data (instrument penelitian) adalah angket kreativitas berupa kuesioner yang terdiri dari 33 butir pernyataan positif dan pernyataan negatif. Instrumen ini menggunakan skala Likert yang terdiri dari lima pilihan respon yaitu: sangat selalu (SL), setuju sering (SR), kadangkadang (KD), jarang (JR), tidak pernah (TP). Rancangan analisis data yangdigunakan adalah analisis deskriptif dan analisis varian (ANAVA) dua jalur. 


\section{HASIL DAN PEMBAHASAN}

\section{Hasil}

Setelah dilakukan pengambilan data pada sampel yang digunakan, diperoleh hasil:

1. Hasil Perhitungan Nilai Rata-rata dan Simpangan Baku :

\section{Tabel 1.}

\section{Hasil perhitungan nilai rata-rata dan simpangan baku Variabel}

\begin{tabular}{|l|r|r|r|r|r|}
\hline & \multicolumn{1}{|c|}{ Descriptive Statistics } \\
\hline N & Minimum & Maximum & Mean & Std. Deviation \\
\hline tes_awal & 30 & 2,39 & 3,58 & 2,9037 & 32781 \\
tes_akhir & 30 & 3,30 & 4,36 & 3,8253 & 31536 \\
Valid N (listwise) & 30 & & & & \\
\hline
\end{tabular}

Hasil menunjukan bahwa rata-rata dari hasil penelitian terkait kreativitas siswa pada tes awal atau sebelum dimulainya pembelajaran adalah adalah 2,9037 dan simpangan bakunya adalah 0,32781 . Nilai rata- rata terkait nilai kreativitas siswa pada tes akhir atau setelah dilakukannya pembelajaran yaitu 3,8253 dan simpangan bakunya adalah 0,31536 .

Tahapan selanjutnya dinamakan uji normalitas, yang mana pada proses perhitungannya memiliki keterkaitan antara nilai rata-rata dan simpangan baku pada setiap variabel. Maksud dari penelitian ini yaitu untuk mengetahui secara benar, apakah sampel tersebut berasal dari distribusi normal atau sebaliknya.

\section{Pengujian Normalitas :}

Setelah diketahui hasil penghitungan nilai rata-rata dan simpangan baku dari masing-masing variabel, maka langkah selanjunya adalah melakukan pengujian normalitas. Pengujian normalitas dilakukan dengan menggunakan pendekatan uji kenormalan Liliefors yaitu uji non parametrik. Sebelum menghitung uji kenormalan Liliefors terlebih dahulu ditetapkan hipotesis.

Dalam hal ini ditetapkan hipotesis nol yaitu : Sampel berasal dari populasi dengan berdistribusi normal. Untuk menerima atau menolak hipotesis nol caranya yaitu membandingkan nilai L hitung ( Lo ) dengan nilai kritis L yang diambil dari tabel uji Liliefors.

Setelah dihitung didapat hasil penghitungan seperti tertera dalam tabel 2 berikut ini : 


\section{Tabel 2}

\section{Hasil Penghitungan Uji Normalitas dari Kedua Variabel}

\begin{tabular}{|l|r|r|r|r|r|r|}
\hline \multirow{2}{*}{} & \multicolumn{3}{|c|}{ Kolmogorov-Smirnow ${ }^{\circ}$} & \multicolumn{3}{|c|}{ Shapiro-Wilk } \\
\cline { 2 - 7 } & \multicolumn{1}{|c|}{ Statistic } & \multicolumn{1}{c|}{ Df } & \multicolumn{1}{c|}{ Sig. } & \multicolumn{1}{c|}{ Statistic } & \multicolumn{1}{c|}{ df } & \multicolumn{1}{c|}{ Sig. } \\
\hline tes_awal &, 095 & 30 &, 200 &, 959 & 30 &, 284 \\
tes akhir &, 130 & 30 &, $200^{\circ}$ &, 947 & 30 &, 139 \\
\hline
\end{tabular}

Berdasarkan penghitungan menggunakan SPSS 22 dari data yang diambil dengan $\mathrm{df}=30$ maka untuk mengetahui nilai normalitas penulis melihat hasil dari Shapiro-Wilk karena df $<50$. Jika nilai signifikansi lebih besar dari 0,05 maka data tersebut berdistribusi normal, dan sebaliknya jika data tersebut lebih kecil dari 0,05 maka data tersebut berdistribusi tidak normal.

Berdasarkan Output diatas bahwa nilai signifikansi tes awal sebesar 0,284 dan nilai signifikansi tes akhir sebesar 0,139 maka dapat dikatakan bahwa data tersebut berdistribusi normal.

\section{Penghitungan T-Test Sampel}

Berhubungan : Perhitungan T-test sampel berhubungan ini dilakukan untuk melihat hubungan sebelum dan sesudah pembaharuan, apakah terjadi peningkatan atau tidak. Hal ini sesuai dengan penelitian penulis, dimana kuesioner yang disebarkan membahas kreativitas yang kemudian akan dilihat hasilnya. Berikut ini hasil perhitungan t-test sampel berhubungan menggunakan SPSS 22 pada Tabel 3 :

\section{Tabel 3}

\section{Hasil penghitungan Paired Sample Test}

\begin{tabular}{|c|c|c|c|c|c|c|c|c|}
\hline & \multicolumn{5}{|c|}{ Paired Differences } & \multirow[b]{3}{*}{$t$} & \multirow[b]{3}{*}{$d f$} & \multirow{3}{*}{$\begin{array}{l}\text { Sig. } \\
(2- \\
\text { tailed) }\end{array}$} \\
\hline & \multirow[b]{2}{*}{ Mean } & \multirow{2}{*}{$\begin{array}{c}\text { Std. } \\
\text { Deviation }\end{array}$} & \multirow{2}{*}{$\begin{array}{l}\text { Std. } \\
\text { Error } \\
\text { Mean }\end{array}$} & \multicolumn{2}{|c|}{$\begin{array}{l}95 \% \text { Confidence } \\
\text { Interval of the } \\
\text { Difference }\end{array}$} & & & \\
\hline & & & & Lower & Upper & & & \\
\hline $\begin{array}{l}\text { Pair tes_awal } \\
1 \quad \text { - } \\
\text { tes_akhir }\end{array}$ &, 92167 &, 46262 & 08446 & 1,09441 &, 748892 & 10,912 & 29 &, 000 \\
\hline
\end{tabular}

Hipotesis untuk kasus t-test adalah $\mathrm{H}_{0}: \mu_{\mathrm{d}} \geq 0$ artinya, bahwa rata-rata hasil tes akhir tidak meningkat dibandingkan tes awal. Sedangkan $\mathrm{H}_{0}: \mu_{\mathrm{d}}<0$ artinya, bahwa hasil tes akhir meningkat dibandingkan tes awal. Nilai yang didapat yaitu dengan membandingkan $\mathrm{T}$ tabel dan $\mathrm{T}$ hitung, dimana $\mathrm{T}$ tabel adalah nilai $\mathrm{T}$ yang terdapat pada tabel statistic, dan T hitung adalah hasil dari perhitungan SPSS 22.

Untuk menentukan $\mathrm{t}$ tabel, dengan tingkat signifikansi $5 \%,(\alpha=0,05)$, sedangkan degree of freedom (df) sebesar $n-1=29(\mathrm{n}=30)$. Sehingga untuk $\alpha=0,05, \mathrm{t}_{(0,05 ; 30)}$ pada $\mathrm{T}$ 
tabel satu sisi (one tail) diperoleh -1,699. Sedangkan dari hasil SPSS 22 di atas, pada kolom ' $t$ ' diperoleh nilai t hitung sebesar -10,912.

Kaidah keputusan dengan membandingkan $\mathrm{T}$ tabel dan $\mathrm{T}$ hitung yaitu, jika $\mathrm{t}$ hitung $\geq \mathrm{t}$ tabel, maka $\mathrm{H}_{0}$ diterima. Dan jika $\mathrm{t}$ hitung $<\mathrm{t}$ tabel, maka $\mathrm{H}_{0}$ ditolak.

Berdasarkan kaidah keputusan di atas, maka karena $t$ hitung $(-10,912)<\mathrm{t}$ tabel $(-1,699)$, maka $\mathrm{H}_{0}$ ditolak, artinya bahwa rata-rata tes akhir meningkat dibandingkan tes awal. Sehingga dapat disimpulkan bahwa penerapan model pembelajaran Project Based Learning meningkatkan kreativitas gerak jurus prasetya mahasiswa pada perkuliahan pencak silat.

\section{Pembahasan}

Dari hasil penelitian yang telah dideskripsikan di atas, menunjukkan bahwa adanya peningkatan kreativitas belajar Jurus Prasetya Pencak Silat pada mahasiswa Kelas 3E PJKR STKIP Pasundan. Hal tersebut menunjukkan adanya pengaruh yang signifikan dari penerapan Model Pembelajaran Project Based Learning terhadap kreativitas belajar Pencak Silat Jurus Prasetya.

Pencak silat adalah beladiri tradisional Indonesia yang perkembangannya sangat pesat dengan semakin banyak orang dari berbagai macam negara lain yang mempelajari pencak silat yang berakar dari budaya melayu dan bisa ditemukan hampir di seluruh wilayah Indonesia dan setiap daerah memiliki kekhasan ciri gerakannya sendiri-sendiri (Maryono, 1999). Selain itu pencak silat sebagai hasil budaya manusia Indonesia untuk membela atau mempertahankan eksistensi dan intengritasnya terhadap lingkungan hidup atau alam sekitarnya untuk mencapai keselarasan hidup guna meningkatkan iman dan taqwa kepada Tuhan Yang maha Esa (Asikin \& Silat, n.d.).

Sebagai identitas seni beladiri nusantara kebudayaan Indonesia berisi tentang pendidikan yang berkembang dalam masyarakat. Dalam dunia modern, silat bukan hanya sebagai alat seni bela diri tetapi berkembang menjadi sebuah upaya dalam memelihara kesehatan melalui olahraga (Shinohara, 1979). Silat berfungsi juga sebagai sarana pendidikan jasmani dan rohani melalui proses tahapan pendidikan berjenjang secara formal melalui peraturan yang dibuat masing-masing perguruan silat.

Terdapat 4 aspek utama dalam pencak silat, yaitu: (1) Aspek Mental Spiritual, pencak silat membangun dan mengembangkan kepribadian dan karakter mulia seseorang. Para pendekar dan maha pengajar pencak silat zaman dahulu seringkali harus melewati tahapan semadi, tapa, atau aspek kebatinan lain untuk mencapai tingkat tertinggi keilmuannya; (2) Aspek Seni Budaya, budaya dan permainan "seni" pencak silat ialah salah satu aspek yang sangat penting. Istilah Pencak pada umumnya menggambarkan 
bentuk seni tarian pencak silat, dengan musik dan busana tradisional; (3) Aspek Beladiri, kepercayaan dan ketekunan diri ialah sangat penting dalam menguasai ilmu beladiri dalam pencak silat. Istilah silat, cenderung menekankan pada aspek kemampuan teknis bela diri pencak silat; (4) Aspek Olah Raga, ini berarti bahwa aspek fisik dalam pencak silat ialah penting. Pesilat mencoba menyesuaikan pikiran dengan olah tubuh. Kompetisi ialah bagian aspek ini. Aspek olahraga meliputi pertandingan dan demonstrasi bentukbentuk jurus, baik untuk tunggal, ganda atau regu (Yuniadi \& Lubis, 2018).

Selain itu terdapat teknik - teknik pencak silat dasar : (1) Pembentukan sikap, terdiri dari sikap berdiri tegak, sikap jongkok, sikap duduk, sikap berbaring, sikap khusus, sikap pasang, sikap kuda-kuda; (2) Pembentukan gerak, terdiri bentuk/pola langkah arah, langkah posisi, bentuk pola langkah; (3) Teknik dasar pukulan, terdiri dari pukulan depan, pukulan samping, serangan/pukulan bawah, serangan/pukulan atas; (4) Serangan siku; (5) Teknik elakan terdiri dari elakan dan tangkisan; (6) Pukulan terdiri dari pukulan lurus, pukulan sangkal atau pukulan bandul, tebasan, patukan, dobrakan, sikuan; (7) tedangan teridri dari tendnagan lurus, tendangan jejag, tendangan $\mathrm{T}$, tendangan belakang; (8) Sapuan; (9) Guntingan; (10) Bantingan; (11) Hindaran; (12) Elakan; dan (13) Tangkisan(AQIL AZIZI, 2013).

Jurus prasetya meliputi rangkain gerak dasar jurus pencak silat yang dirangkai diiringi musik, gerak jurus prasetya yang sudah baku dapat dikreasikan dengan menambahkan variasi pola langkah tanpa mengubah jurus prasetya di dalam kelompok, mahasiswa dapat mengkerasikan dengan kreativitas rangkaian gerak jurus prasetya, kemudian dipersentasikan di depan kelas dan diaplikasikan dalam bentuk video/cd sebagai proyek akhir hasil pembelajaran.

Pembelajaran pencak silat yang diberikan pada perkulihan pencak silat di STKIP Pasundan terdiri dari rangkaian gerak dasar jurus prasetya dan jurus wajib yang terdiri dari 100 jurus. Apabila dilihat dari materi yang diberikan, tugas mahasiswa hanya menghafal setiap gerakan yang diberikan pengajar sebagai nilai akhir perkuliahan. Sehingga penilain akhir hanya berdaskan tingkat hafalan dan gerakan yang sempurna yang dilakukan oleh mahasiswa.

Berdasarkan uraian di atas terdapat suatu model yang dapat digunakan sebagai pembelajaran pencak silat, yaitu dengan model Project Based Learning. Pembelajaran berbasis proyek sangat penting untuk meningkatkan kuantitas aktivitas mahasiswa dan mengandung beberapa proses pembelajaran yang berbeda (Rati \& Kusmaryatni, 2017). Diharapkan dengan diberikan model Project Based Learning, mahasiswa dapat lebih berkreativitas saat belajar bersama teman-temannya dan bisa memberikan kesempatan 
kepada temannya untuk mengemukakan gagasan dengan menyampaikan pendapat mereka secara berkelompok sehingga pembelajaran akan menyenangkan (Izzati, 2014).

Model Project Based Learning merupakan model pembelajaran yang memiliki kegiatan belajar mengajar berbasis proyek. Model Project Based Learning ini melakukan kegiatan proyek yang dilaksanakan oleh mahasiswa dengan bimbingan pengajar. Model pembelajaran berbasis proyek (Project Based Learning) ini model pembelajaran yang secara langsung melibatkan mahasiswa dalam proses pembelajaran melalui kegiatan penelitian untuk mengerjakan dan menyelesaikan suatu proyek pembelajaran tertentu (Lee et al., 2014).

Model pembelajaran berbasis proyek dapat menstimulasi motivasi, proses, dan meningkatkan prestasi belajar siswa menggunakan masalah-masalah yang berkaitan dengan materi tertentu pada situasi nyata. Dalam pembelajaran berbasis proyek masalah yang diberikan merupakan suatu konteks bagi siswa untuk belajar tentang cara berpikir kritis dan keterampilan pemecahan masalah serta memperoleh pengetahuan dan konsep yang esensial dari materi pelajaran (Digital et al., 2016). Pada proses pemecahan masalah, siswa dapat bertukar pendapat dan bekerjasama dengan teman kelompoknya sehingga penguasaan materinya meningkat dan akhirnya siswa mampu mencapai hasil belajar yang optimal.

Proyek yang dikerjakan oleh mahasiswa dapat berupa proyek perseorangan atau kelompok dan dilaksanakan dalam jangka waktu tertentu secara kolaboratif, menghasilkan sebuah produk, yang hasilnya kemudian akan ditampilkan dan dipresentasikan. Pembelajaran berbasis proyek merupakan metode belajar yang menggunakan masalah sebagai langkah awal dalam mengumpulkan dan mengintegrasikan pengetahuan baru. Mahasiswa menjadi terdorong lebih aktif di dalam belajar mereka, dosen berposisi di belakang dan mahasiswa yang kebih berinisiatif, dosen memberi kemudahan dan mengevaluasi hasil proyek baik maknanya maupun penerapannya untuk kehidupan mereka sehari-hari.

Fokus pembelajaran terletak pada konsep-konsep dan prinsip-prinsip inti dari suatu disiplin studi, melibatkan pelajar dalam investigasi pemecahan masalah dan kegiatan tugas-tugas bermakna yang lain, memberi kesempatan pelajar berkerja secara otonom mongkonstruksi pengetahuan mereka sendiri dan mencapai puncaknya menghasilkan produknya (Meyer \& Wurdinger, 2016).

Dalam proses pembelajaran diperlukan solusi untuk memecahkan permasalahanpermasalahan yang ditemui dalam proses pembelajaran khususnya permasalahan mengenai rendahnya hasil belajar peserta didik. Untuk mengatasi rendahnya hasil belajar 
tersebut, dalam proses pembelajaran pengajar harus menerapkan model pembelajaran yang inovatif. Salah satu model pembelajaran inovatif yang dapat digunakan dalam proses pembelajaran adalah model pembelajaran berbasis proyek (Project Based Learning). Dalam model pembelajaran berbasis proyek melalui enam tahapan pembelajaran yaitu: (1) start with the essential question, (2) design a plan for the project, (3) create a schedule, (4) monitor the students and the progress of the project, (5) asses the outcome, (6) evaluate the experiences (AMANDA \& Tika, 2014).

Kelebihan Project Based Learning : (1) Meningkatkan motivasi; (2) Meningkatkan kemampuan pemecahan masalah; (3) Meningkatkan Kolaborasi; (4) Meningkatkan keterampilan mengelola sumber; (5) Model ini bersifat terpadu dengan kurikulum sehingga tidak memerlukan tambahan apapun dalam pelaksanaannya; (6) mahasiswa terlibat dalam kegiatan dunia nyata dan mempraktikan strategi otentik secara disiplin(Siswanto, 2012).

Kemampuan kreativitas adalah kemampuan dan sikap seseorang untuk membuat produk yang baru. Kreativitas bukanlah mengadakan sesuatu yang tidak ada menjadi ada, akan tetapi kretivitas adalah kemampuan untuk menghasilkan ide-ide baru dengan cara membuat kombinasi, membuat perubahan, atau mengaplikasikan ide-ide yang ada pada wilayah yang berbeda. Indikator kemampuan berpikir kreatif terbagi menjadi tiga hal, yaitu: 1. Fluency (kelancaran), yaitu menghasilkan banyak ide dalam berbagai kategori/ bidang. 2. Originality (Keaslian), yaitu memiliki ide-ide baru untuk memecahkan persoalan. 3 Elaboration (Penguraian), yaitu kemampuan memecahkan masalah secara detail(Wahida et al., 2015).

Secara umum pembelajaran berbasis proyek menempuh tiga tahap yaitu perencanaan proyek, pelaksanaan proyek, dan evaluasi proyek. Kegiatan perencanaan meliputi: identifikasi masalah riil, menemukan alternatif dan merumuskan strategi pemecahan masalah, dan melakukan perencanaan. Tahap pelaksanaan meliputi pembimbingan mahasiswa dalam penyelesaian tugas, dalam melakukan pengujian produk (evaluasi), presentasi antar kelompok. Tahap evaluasi meliputi penilaian proses dan produk yang meliputi: kemajuan belajar proyek, proses aktual dari pemecahan masalah, kemajuan kenerja tim dan individual, buku catatan dan masalah, kemajuan kenerja tim dan individual, buku catatan dan catatan penelitian, kontrak belajar, penggunaan komputer, refleksi. Sedangkan penilaian produk seperti hasil kerja dan presentasi, tugastugas non tulis, dan laporan proyek (Lee et al., 2014).

Langkah-langkah implementasi pembelajaran model Project Based Learning dalam mata kuliah pencak silat adalah sebagai berikut : 
1. Penentuan proyek, pada langkah ini mahasiswa menentukan tema/topik proyek berdasarkan tugas proyek yang diberikan oleh pengajar. Peserta didik diberi kesempatan untuk mengembangkan dari jurus prasetya ke dalam suatu proyek yang akan dikerjakannya secara kelompok dengan catatan tidak menyimpang dari tugas yang diberikan pengajar.

2. Perancangan langkah-langkah kegiatan penyelesaian proyek dari awal sampai akhir dengan kelompoknya. Kegiatan perancangan proyek ini berisi aturan main dalam pelaksanaan tugas proyek, pemilihan aktivitas yang dapat mendukung tugas proyek, pengintegrasian berbagai kemungkinan penyelesaian tugas proyek, perencanaan sumber/bahan/alat yang dapat mendukung penyelesaian tugas proyek, dan kerja sama antar anggota kelompok.

3. Penyusunan jadwal pelaksanaan proyek mahasiswa di bawah pengawasan pengajar pada saat jadwal perkulihaan, langkah ini merupakan langkah pengimplementasian rancangan proyek yang telah dibuat. Aktivitas yang dapat dilakukan dalam kegiatan proyek di antaranya adalah dengan a) membaca, b) meneliti, c) observasi, d) interviu, e) merekam, f) berkarya seni, g) mengunjungi objek proyek, atau h) akses internet. Pengajar bertanggung jawab memonitor aktivitas peserta didik dalam melakukan tugas proyek mulai proses hingga penyelesaian proyek.

4. Penyusunan laporan dan presentasi/publikasi hasil proyek dalam bentuk produk, dalam hal ini mahasiswa dapat menghasilkan produk gerakan jurus prasetya yang dimodifikasi dalam bentuk video/cd, dipresentasikan dan dipublikasikan kepada peserta didik yang lain serta masyarakat luas.

5. Evaluasi proses dan hasil proyek pengajar akhir dilakukan refleksi terhadap aktivitas dan hasil tugas proyek. Proses refleksi pada tugas proyek dapat dilakukan secara kelompok. Pada tahap evaluasi, mahasiswa diberi kesempatan mengemukakan pengalamannya selama menyelesaikan tugas proyek yang berkembang dengan diskusi untuk memperbaiki kinerja selama menyelesaikan tugas proyek. Pada tahap ini juga dilakukan umpan balik terhadap proses dan produk yang telah dihasilkan.

Hasil penelitian ini memberikan manfaat dalam penerapan pembelajaran berbasis proyek diantaranya adalah sebagai berikut: (1) Mahasiswa memperoleh pengetahuan dan keterampilan baru dalam pembelajaran; (2) Mahasiswa dapat meningkatkan kemampuan dalam pemecahan masalah; (3) Mahasiswa lebih aktif dalam melaksakan proses pembelajaran pencak silat; (4) Mahasiswa dapat mengembangkan dan meningkatkan keterampilan dalam mengelola sumber/bahan/alat untuk menyelesaikan 
tugas; (5) Meningkatkan kolaborasi mahasiswa khususnya pada pembelajaran yang bersifat kelompok(Wahida et al., 2015).

Hasil analisi data nilai sig 2-tailed sebesar $0,0000<0,05$, membuktikan bahwa adanya pengaruh yang signifikan dari penerapan Model Pembelajaran Project Based Learning terhadap kreativitas belajar Pencak Silat Jurus Prasetya.

Penelitian ini mendukung dan memberikan gambaran baru bahwa dengan menerapkan model pembelajaran Project Based Learning dapat meningkatkan kerativitas mahasiswa dalam jurus prasetya. Hasil penelitian ini juga mendukung hasil penelitian terdahulu yang menggunakan model project based learning dapat mendorong tumbuhnya kerativitas, kemandirian, tanggung jawab, kepercayaan diri, serta berfikir kritis dan analistis pada peserta didik(Meyer \& Wurdinger, 2016). Penerapan model pembelajaran Project Based Learning berbantuan media kartu bergambar dapat berpengaruh signifikat terhadap peningkatan hasil belajar tekmik dasar kuda-kuda pencak silat(Ayu et al., 2018). Penerapan model pembelajaran berbasis proyek berpengaruh signifikan terhadap keterampilan berpikir keratif dan hasil belajar siswa kimia(Wahida et al., 2015). Terdapat pengaruh yang positif model pembelajaran berbasis proyek terhadap kreativitas mahasiswa; Terdapat pengaruh yang positif model pembelajaran berbasis proyek terhadap hasil belajar Pendidikan IPA SD mahasiswa; dan Terdapat pengaruh yang positif model pembelajaran berbasis proyek terhadap hasil belajar Pendidikan IPA SD mahasiswa secara simultan(Rati \& Kusmaryatni, 2017). Hasil penelitian menunjukkan bahwa penerapan PBL dapat meningkatkan motivasi dan hasil belajar mata kuliah Pengantar Ekonomi Pembangunan pada mahasiswa jurusan Manajemen FE Unimed(Hutasuhut, 2010).

\section{KESIMPULAN}

Berdasarkan hasil penelitian ini dapat ditarik kesimpulan bahwa adanya pengaruh yang signifikan dari penerapan Model Pembelajaran Project Based Learning terhadap kreativitas belajar Pencak Silat Jurus Prasetya.

\section{DAFTAR PUSTAKA}

Amanda, N., \& Tika, M. (2014). Pengaruh Model Pembelajaran Berbasis Proyek Terhadap Hasil Belajar Ipa Ditinjau Dari Self Efficacy Siswa. Jurnal Pendidikan Dan Pembelajaran IPA Indonesia, 4(1).

Aqil Azizi, M. (2013). Pengaruh Latihan Split Jump Terhadap Peningkatan Kecepatan Tendangan Depan Pada Pencak Silat. Jurnal Kesehatan Olahraga, 1(1).

Asikin, R., \& Silat, P. P. (n.d.). R. Asikin, Pelajaran Pencak Silat, (Bandung: Tarate, 
1975), hlm. 9. 1. 1-33.

Ayu, I., Indra, M., Astra, I. K. B., Suwiwa, I. G., Jasmani, J. P., \& Rekreasi, K. D. (2018). E_ Journal Pendidikan Jasmani , Kesehatan dan Rekreasi Fakultas Olahraga dan Kesehatan, Undiksha, Volume 8, Nomor 2 ( 2017 ) E_ Journal Pendidikan Jasmani, Kesehatan dan Rekreasi PENDAHULUAN Sejalan dengan perubahan kurikulum, guru dituntut untuk k. 8(2017).

Bereiter, C., \& Scardamalia, M. (2000). Process and product in Problem-Based Learning (PBL) research. Problem- Based Learning, A Research Perspective on Learning Interactions, 185-195. http://www.ikit.org/fulltext/2000Process.pdf

Digital, P. B., Peningkatan, U., Abad, K., Guru, C., Dasar, S., Model, M., Berbasis, P., Finita, P., Model, A., Guru, P., Dasar, S., Purwakarta, U. P. I. K., Kuliah, M., Bahasa, P., Tinggi, K., Purwakarta, U. P. I., Kunci, K., Digital, B., Guru, C., ... Purwakarta, K. (2016). Proyek Buku Digital: Upaya Peningkatan Keterampilan Abad 21 Calon Guru Sekolah Dasar Melalui Model Pembelajaran Berbasis Proyek. Metodik Didaktik, 9(2), 1-15. https://doi.org/10.17509/md.v9i2.3248

Fraenkel, Jack R., Wallen, N. E. (2009). How to Design and Evaluate Research in Education. In McGraw-Hill Higher Education (7th ed.). McGraw-Hill Higher Education. https://doi.org/10.1017/CBO9781107415324.004

Hutasuhut, S. (2010). Implementasi Pembelajaran Berbasis Proyek (Project-Based Learning ) Untuk Meningkatkan Motivasi Dan Hasil Belajar Mata Kuliah Pengantar Ekonomi Pembangunan Pada Jurusan Manajemen Fe Unimed. Pekbis Jurnal, 2(1), 196-207. https://media.neliti.com/media/publications/8944-ID-implementasipembelajaran-berbasis-proyek-project-based-learning-untuk-meningkat.pdf

Izzati, N. (2014). PENGARUH PENERAPAN MODEL PEMBELAJARAN BERBASIS PROYEK TERHADAP KEMAMPUAN BERPIKIR KREATIF MAHASISWA (Studi Kuasi Eksperimen terhadap Mahasiswa Tadris Matematika IAIN Syekh Nurjati Cirebon). Eduma: Mathematics Education Learning and Teaching, 3(1). https://doi.org/10.24235/eduma.v3i1.7

Lee, J. S., Blackwell, S., Drake, J., \& Moran, K. A. (2014). Taking a Leap of Faith: Redefining Teaching and Learning in Higher Education Through Project-Based Learning. Interdisciplinary Journal of Problem-Based Learning, 8(2), 3-13. https://doi.org/10.7771/1541-5015.1426

Maryono, O. (1999). Pencak Silat in the Indonesian Archipelago. RAPID Journal, 4(2).

Meyer, K., \& Wurdinger, S. (2016). Students' Perceptions of Life Skill Development in Project-Based Learning Schools. Journal of Educational Issues, 2(1), 91. https://doi.org/10.5296/jei.v2i1.8933

Punkastyo, D. A. (2018). Perancangan Aplikasi Tutorial Jurus Dasar Beladiri Cimande Menggunakan Metode Prototype. Jurnal Informatika Universitas Pamulang, 3(2), 87. https://doi.org/10.32493/informatika.v3i2.1433

Rati, N. W., \& Kusmaryatni, N. (2017). Model Pembelajaran Berbasis Proyek, Kreativitas Dan Hasil Belajar Mahasiswa. Jurnal Pendidikan Indonesia, 6(1), 6071.

Shinohara, H. (1979). Fluid Characteristics of Continuous Multi-Perforated Plate Stage 
Fluidized Beds without Downcomer Discharge of solid particles in the region of stable fluidization. Kagaku Kogaku Ronbunshu, 5(3), 275-280. https://doi.org/10.1252/kakoronbunshu.5.275

Siswanto, J. (2012). Compact Disk Online (Cd-O) Sebagai Multimedia Interaktif Pembelajaran Fisika Berbasis Proyek. Jurnal Penelitian Pembelajaran Fisika, 2(1/April), 52-64. https://doi.org/10.26877/jp2f.v2i1/april.127

Solomon, B. G. (2008). techLEARNING . com | Technology \& Learning - The Resource for Education Technolog ... Project-Based Learning: a Primer techLEARNING . com | Technology \& Learning - The Resource for Education Technolog ... Page 2 of 3. Technology \& Learning, 2-4.

Wahida, F., Rahman, N., \& Gonggo, T. (2015). Pengaruh Model Pembelajaran Berbasis Proyek terhadap Keterampilan Berpikir Kreatif dan Hasil Belajar Siswa Kelas X Sma Negeri 1 Parigi. Sains Dan Teknologi Tadulako, 4(3), 36-43.

Wurdinger, S., \& Rudolph, J. (2009). A different type of success: Teaching important life skills through project based learning. Improving Schools, 12(2), 115-129. https://doi.org/10.1177/1365480209105576

Yuniadi, A., \& Lubis, N. H. (2018). Penca Existence among the Sundanese. Penca Existence among the Sundanese, 3(2), 103-112. https://doi.org/10.17509/mimbardik.v3i2.13948 